\title{
STRATEGY OF DEVELOPMENT OF LOGISTIC INFRASTRUCTURE OF UKRAINE IN THE CONDITIONS OF EUROPEAN INTEGRATION
}

\author{
Olga Shkurenko ${ }^{1 *}$ and Maryna Savchenko ${ }^{2^{*}}$ \\ ${ }^{1}$ State University of Infrastructure and Technology, Business Logistics and Transport Technologies \\ Department, Ogienko st. 19, 03049 Kyiv, Ukraine \\ 2 Vasyl' Stus Donetsk National University, International Economic Relations Department, \\ Akademika Yangel st. 4, 21007, Vinnytsa, Ukraine
}

\begin{abstract}
The article defines the role and place of logistics infrastructure in the development of the country's economy. The division of the transport and logistics centers of the European Union into five groups is substantiated: the main general, the main parts of European importance, secondary regional significance, auxiliary national and auxiliary regional centers. The problems of formation and development of logistic infrastructure of Ukraine are investigated. The state of development of logistic infrastructure of European countries and Ukraine is investigated, and their competitive advantages are determined. A comparative analysis of the transport infrastructure of Ukraine and Poland is carried out. The authors define the principles of forming logistics centers: security, competitiveness, openness, interaction and organizational management, implementation of which will enable the formation of an effective logistic infrastructure of Ukraine and, as a result, will increase its competitiveness in and positions in international ratings.
\end{abstract}

\section{Introduction}

The current conditions of Eurointegration, which Ukraine aspires to, demands increasing improvement, growth and attention in the field of freight transportation logistics. The quality and efficiency of freight transport depends on optimization of coordination processes of different types of transport, distribution of volumes of transportation, design of logistics freight transportation systems, and the clear formation of necessary management decisions [1-4]. Today, one of the most important issues for Ukraine is the formation of an infrastructure that, according to international standards, meets economic principles and forms different spheres of activity and could sufficiently satisfy market demand on the basis of reliability, quality, timeliness and minimum costs. That is why studies related to comparing the effectiveness of the Ukrainian logistics infrastructure with international ratings able to provide a continuous flow of all necessary logistics operations are relevant.

*Corresponding author:_dondyy@ukr.net, m_savchenko@donnu.edu.ua, 


\section{Degree of Problem Development}

Thorough studies of the logistics infrastructure are generally undertaken by such foreign and domestic scientists as A. Harrison, D. Lambert, E. Krikavsky, N. Chornopyska, M. Dovba, O. Sumets, T. Babenkova, M. Grigorak, V. Kolodin, Y. Kuzmenko, V. Kopytko, N. Savina [1-8]. In their publications, the content of the definition of "logistics infrastructure" is deduced, as well as its components and operating conditions are considered. Despite the significant scientific achievements in the study of infrastructure development, in particular logistics, there are still insufficient research issues regarding the implementation of foreign experience in infrastructure management in domestic practice.

\section{Research results}

One of the most important meanings for efficient functioning of the economy is the highly developed logistics infrastructure, which would provide a sufficiently low cost of transportation to markets of other regions and countries, reduce the impact on the distance between different regions, and ensure the integration of the national market. A prerequisite for access to high-quality and advanced economic services and processes of the least developed settlements is highly developed transport infrastructure. Highways and railways, airports and high quality ports, i.e., efficient modes of transport, guarantee for entrepreneurs systematic and absolutely timely delivery of their services and products to the market. The highly developed telecommunications network provides a fast and uninterrupted information flow. This allows market players to make optimal decisions for the full amount of available efficiency and improve overall economy performance.

In Western European countries, one of the most significant sphere, is the share of logistics services in the economy. The European countries in which the number of employees employed in the enterprise leads the provision of auxiliary transport services, such as Germany, France, Italy, Spain and the United Kingdom are worth highlighting. In Italy, one of the largest transport and logistics centers in the European Union, called Bologna Freight Village, is located at the intersection of four motorways and five major railways. This transport and logistics center serves about $16 \%$ of international cargo and $35 \%$ of freight Italian traffic. Bologna Freight Village includes almost 100 logistic and transport companies from all over the world, and includes customs, mail, banking institutions, restaurants and hotels.

As a result of the rich historical practice regarding the introduction of transport and logistics centers and their research within the European Union, the classification of transport and logistics centers was carried out into five categories: main transport and logistics centers of the general European value; main transport and logistics centers of partial European significance; secondary transport and logistics centers of regional importance; auxiliary national transport and logistics centers; auxiliary regional transport and logistics centers. Most of the major transport and logistics centers of the European Union are created with the support from the government. All European transport and logistics centers are subject to a generally accepted structure. In recent years, one of the main pillars of the European transport policy has been the development of piggyback cargo transport, which predicts the operation of transport chains as a single and continuous transport container, based on the principles of logistics. Almost one-third of all international door-to-door freight traffic is carried out thanks to container trains, as evidenced by international practice [8, p.21]. Since the goods are provided with the door-todoor principle, road and rail transport, in particular container transportation, turns from 
partners into competitors. Ukraine in its development of logistics infrastructure is not in the best position, it is on the $137^{\text {th }}$ place out of 144 in the rating of the international nongovernmental organization The World Economic Forum on Road Quality [9]. Rather a big problem of Ukraine is an inadequate quality of most of the transport, and first of all, roads. Even the most developed and modern logistics center cannot provide high-quality and fast delivery of goods, if there is no participation of the organization responsible for the state of the regional highways [2]. According to estimates of transport infrastructure, Ukraine is significantly inferior to highly developed infrastructure leaders, as shown by a detailed analysis of the LPI index. But it is interesting to note that surveys of logistics operators have showed that Ukraine has no problems finding logisticians with high qualifications, while in Germany, about $34-37 \%$ have difficulty in finding candidates for managerial positions and almost $41 \%$ are in the search for skilled managers in the field of logistics. In comparison with Germany, Ukraine, of course, lags behind in the development of logistics infrastructure, and also shows a negative dynamics, if it is compared even to countries whose incomes are lower than the average (Table 1).

Table 1. - The value of LPI in countries whose incomes are below the average for 2015 and 2017

\begin{tabular}{|l|c|c|c|c|}
\hline \multicolumn{1}{|c|}{ Country } & $\begin{array}{c}\text { Place in rating for } \\
2015\end{array}$ & Result for 2015 & $\begin{array}{c}\text { Place in rating for } \\
2017\end{array}$ & $\begin{array}{c}\text { Result for } \\
2017\end{array}$ \\
\hline India & 54 & 3.08 & 35 & 3.42 \\
\hline Kenya & 74 & 2.81 & 42 & 3.33 \\
\hline Egypt & 62 & 2.97 & 49 & 3.18 \\
\hline Vietnam & 48 & 3.15 & 64 & 2.98 \\
\hline Pakistan & 72 & 2.83 & 68 & 2.92 \\
\hline Ukraine & 61 & 2.98 & 80 & 2.74 \\
\hline El Salvador & 64 & 2.96 & 83 & 2.71 \\
\hline Guyana & 124 & 2.46 & 85 & 2.67 \\
\hline
\end{tabular}

Source: composed by the authors on the basis of [5]

For a more detailed consideration of the development of the market for logistic infrastructure services, the state of development of the logistic infrastructure of the countries of Europe and Ukraine should be investigated (Fig. 1). In the context of deepening European integration, the role of transport and transport infrastructure is increasing substantially, as labor mobility and the intensification of both international and domestic commodity circulation are increasing. This forces national governments to seek additional resources for the development of transport and the modernization of transport infrastructure. The transport sector and transport infrastructure of Poland are almost the most developed in the whole of Eastern Europe and serve as an example for many states, in particular for Ukraine. Existing potential for development of transport infrastructure objects was effectively used and developed due to its transition to market principles of functioning. Some of the state-owned companies, including the railways of the Polish National Rail Company "Polskie Koleje Panstwowe" (PKP SA), were stocked, others were included in the field of open market competition. The railway industry, which is one of the main carriers of resources, goods and people, both within the country and on an intergovernmental scale, has developed especially successfully. The most loaded are the railways of the Upper Silesian district, which are transported by coal. One third of the railways are electrified, in particular, the most important highways from Silesia and Krakow through Warsaw to Trumuesti (Gdansk, Gdynia, Sopot); from Silesia to Szczecin, as well as along the entire Polish part of the trans-European highway Hamburg-BerlinWarsaw-Minsk [6]. 


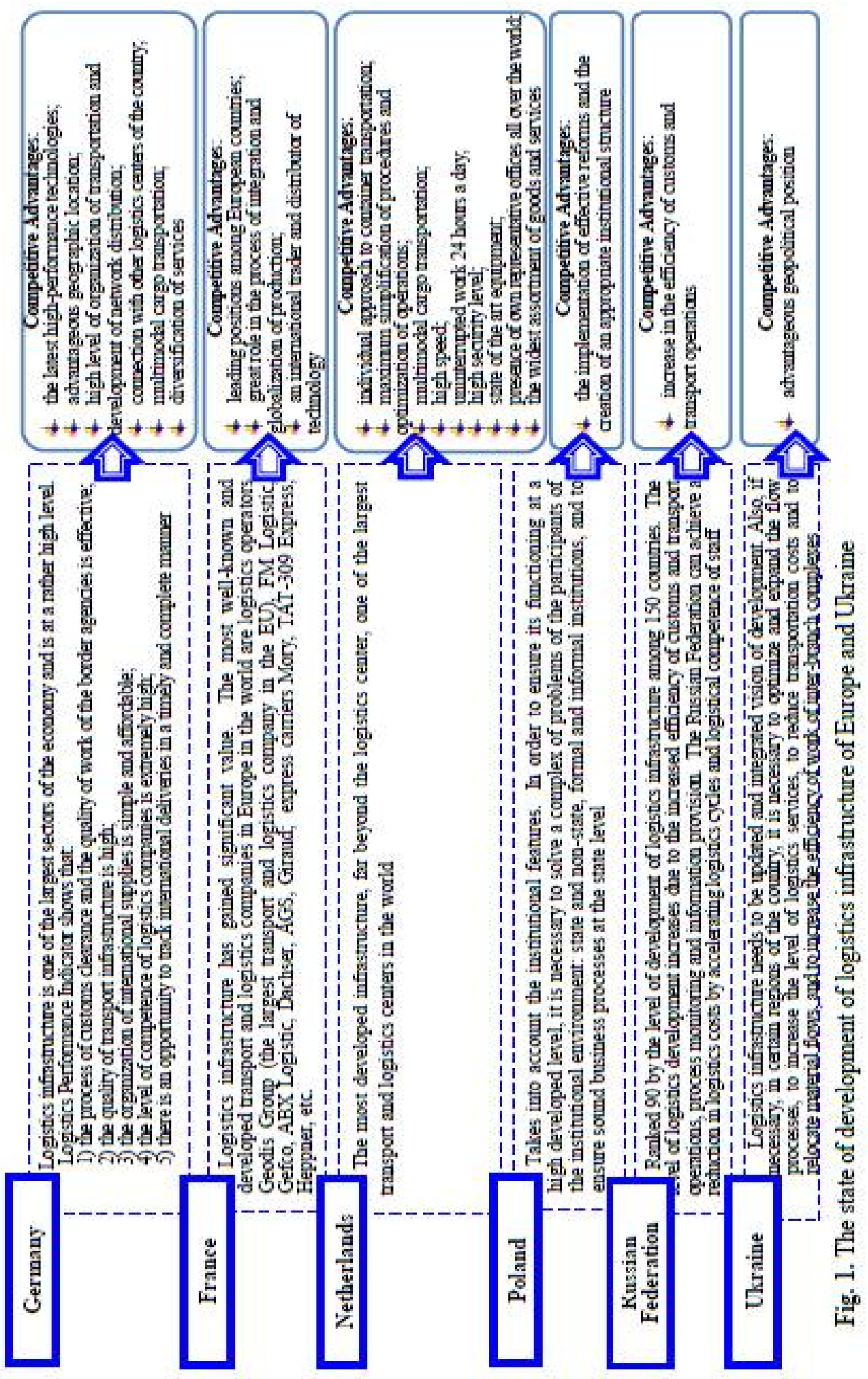


Thanks to the reforms undertaken in preparation for Poland's accession to the EU, the transport infrastructure of the country has undergone fundamental quality as well as significant quantitative changes. As a result of this, in comparison with Ukraine, modern Poland significantly exceeds our country by most indicators (Table 2).

Table 2. Comparison of certain elements of the transport infrastructure of Ukraine and

Poland

\begin{tabular}{|l|c|c|}
\hline \multicolumn{1}{|c|}{ Indexes } & Ukraine & Poland \\
\hline Area, thousand km ${ }^{2}$ & 603.7 & 312.6 \\
\hline Population, million people & 42 & 38 \\
\hline Road length, km & 169.4 & 424.0 \\
\hline Density of roads, km / thousand km ${ }^{2}$ & 280.6 & $1,355.9$ \\
\hline Length of railways, thousand km & 21.7 & 22.3 \\
\hline Electrified railway tracks, thousand km & 10.2 & 11.7 \\
\hline Cargo transportation in 2017, billion tkm & 191 & 31 \\
\hline Number of locomotives (work park) & 2,195 & 1,250 \\
\hline Number of freight cars (working park) & 67,000 & 60,000 \\
\hline $\begin{array}{l}\text { Number of employees of state railway companies, } \\
\text { thousand people }\end{array}$ & 274 & 81 \\
\hline Density of railways, km/thousand km ${ }^{2}$ & 35.9 & 71.4 \\
\hline
\end{tabular}

Source: composed by the authors on the basis of [6-7]

The main problem of Ukraine today is not that the logistics of the infrastructure is deteriorating, but that the provision of general logistics activities in Ukraine is developing much slower than in other countries, this provision of our state significantly reduces the place and rating in the rating.

One can conclude that, if we look at the experience of foreign countries in the creation of transport and logistics centers, for the same quality of construction of centers in Ukraine, the following principles have to be taken into account: cooperation and internal cooperation with transport and logistics centers located on the border with other states or in other regions and districts is required; the proper placement of transport and logistics centers should be observed, so that they are located near airports, railway stations and highways; also transport and logistics centers should be located in those places where high rates of activity of import and export can be clearly observed; transport and logistics centers should be located near the centers of highly developed infrastructure.

Also, in addition to the principles mentioned above, the following principles can be developed for the operation of transport and logistics centers: 1) security - all transport and logistics centers should have in their possession the equipment necessary for transportation of cargo (loading and unloading, tracking of cargo and its control, forwarding, storage and handling of goods, transportation, research, insurance, customs clearance, gas stations, car wash etc.); 2) competitiveness - a large number of logistic, transport and forwarding competing companies in their structure is required; 3) openness - all transport and logistics centers, regardless of their legal and administrative forms, should be accessible to any other companies; 4) interaction - in all transport and logistics centers in order to optimize freight flows, it is necessary to carry out activities related to logistics operations and transport and logistics services in accordance with national and international cooperation; 5) organizational management - transport and logistics centers should be managed by only one governing body - an independent law firm, this company should be located within the transport and logistics center, act on its behalf and protect the interests of the company

\section{Conclusion}


If we take into account the tendencies of European countries in the sector of logistic infrastructure, it is immediately clear that Ukraine is significantly inferior in its development, because it only passes through the stage of formation. Nevertheless, despite all the above, one of the most attractive sectors in the Ukrainian investment sector is the transport logistics.

In order to form an effective strategy for the development of Ukrainian logistic infrastructure in the context of European integration, certain principles and methods of making changes should be applied, namely: accounting for a number of territorial specifications, such as climatic and socio-demographic conditions, geographic location; proper formulation of the goals of functioning and development of logistics infrastructure, as well as accounting for the social and economic development of the country; accounting for all features of management, state of development and provision of governmental resources through its specialization; applying the principle of co-operation to regulate the supply of raw materials between regions; using the principle of complexity of development of the subjects of logistic infrastructure, because they should holistically promote prospective directions and development of the state; accounting for non-partial shifts, and general indicators of activity of logistic infrastructure on the basis of realization of such measures for formation of the national logistic infrastructure, which bring the greatest effect.

Therefore, logistics infrastructure has been one of the most important factors for Ukrainian as well as for the world economy as a whole; therefore, the problems of its development and modernization should be approached in an effective and rational way, as well as to investigate the problems of introducing innovations into the logistic infrastructure.

\section{References}

1. Harrison Alan, Van Hoek Remko. Upravlinnia lohistykoiu: Rozrobka stratehii lohistychnykh operatsii. Per. $\mathrm{z}$ anhl.; Za nauk. red. O.Ie. Mikheitseva. Dnipropetrovsk: Balans Biznes Buks, 368 (2007).

2. Pepich T.A., Velykyi D.Yu. Optymizicija logistychnoi' infpastpuktupy mizhnapodnyh vantazhny perevezen'. Efektyvna ekonomika. 1. (2017).

3. Bondapenko O.S. Obgpuntuvannja sutnosti logistychnoi' infpastpuktupy u finansovyh potokah pidppyjemstv, Investytsii: praktyka ta dosvid, 8, 51-55 (2015).

4. Falovych V.A. Vykopystannia zasobiv lohistychnoi infpastpuktupy $v$ lantsiuhu postavok, Ekonomika i suspilstvo, 10, 389-395 (2017).

5. Arvis J.-F. Connecting to Compete 2016. Trade Logistics in the Global Economy. The Logistics Performance Index and Its Indicators, Communications Development Incorporated, Washington, 62 (2016).

6. Transport $v$ Polshchi [Elektronnyi resurs]. URL: http://www.geograf.com.ua/poland/695-poland-transport/.

7. Kopytko V. Napriamy rozvytku transportnoi infrastruktury Ukrainy, Visn. Dnipropetr. nac. un-tu zalizn. transp. im. akad. V. Lazarjana, Dnipro, 41, 261-265 (2012).

8. Kotenko A.M. Tekhnolohii i tekhnichni zasoby kombinovanykh perevezen vantazhiv za chynnykamy hlobalnoi, 1/2(6), 21-25 (2015).

9. Ukrainski dorohy u desiattsi naihirshykh u sviti. URL: http://zik.ua/news/2017/06/06/u krainski_dorogy_u_desyattsi_naygirshyh_u_sviti_1109301. 